\title{
RECURRENCES OF PTERYGIUM FOLLOWING CONJUCTIVAL AUTO TRANSPLANT IN DIABETIC PATIENT OF TRIPURA: A RETROSPECTIVE STUDY
}

\author{
Amar Kanti Chakma1, Avik Chakraborty², Debasis Datta ${ }^{3}$ \\ ${ }^{1}$ Associate Professor, Department of Ophthalmology, Tripura Medical College. \\ ${ }^{2}$ Associate Professor, Department of General Medicine, Tripura Medical College. \\ 3 Professor and HOD, Department of Ophthalmology, Tripura Medical College.
}

ABSTRACT

AIM

To study the recurrence rate after pterygium excision with conjunctival autograft in diabetic patient.

\section{MATERIAL AND METHODS}

It is a retrospective study conducted at Department of Ophthalmology in collaboration with Department of Medicine from November 2011 to October 2013. All the patients with pterygium were sent to Medicine department for diabetes status and patient with type -2 diabetes were taken up for surgery only after proper diabetic control and fitness given by clinician. Total 100 were divided into group A with diabetes and Group B without diabetes, comprising 50 patients in each group were operated of which 5 and 3 patient in group A and B came with recurrence respectively. All patients were in age group 30 to 60 and above.

\section{RESULTS}

Highest prevalence of pterygium was seen in age group of 40-49 years 18 eyes (36\%) in group A and in group B, age group of 5059 shows the high prevalence around 17 eyes (34\%). During the follow-up period of this study, progressive pterygium recurred in 5 patients of group A and 3 patients in group B. Graft rejection and sub-conjunctival haemorrhage were noted complication in both the group. The average duration of recurrence was 5.3 months. The mean age of the patients with recurrence was 43.3 years.

\section{CONCLUSION}

Autogenous conjunctival grafting is a safe, uncomplicated, quick procedure with low recurrence rate. There is no significant difference in recurrences in diabetic and non-diabetic patients except delayed in healing in diabetic patients.

\section{KEYWORDS}

Conjunctival Autograft, Primary Pterygium, Recurrent Pterygium, Diabetes Mellitus.

HOW TO CITE THIS ARTICLE: Chakma AK, Chakraborty A, Datta D. "Recurrences of pterygium following conjunctival auto transplant in diabetic patient of Tripura: A retrospective study." Journal of Evolution of Medical and Dental Sciences 2015; Vol. 4, Issue 105, December 31; Page: 17043-17045, DOI: 10.14260/jemds/2015/2580

\section{INTRODUCTION}

Pterygium is a fibrovascular, wing shaped encroachment of the conjunctiva on to the cornea.[1] It is common worldwide, but is particularly prevalent in tropical and sub-tropical areas. Since the days of Susruta, the world's first ophthalmic surgeon who recognized the pterygia, disturbing both the patient because of their unsightly appearance and the surgeon also by their tendency to recur. Its incidence varies across geographical sites. The prevalence rates of pterygia range from 0.7 to $31 \%$ among different populations and are also influenced by age, race and exposure to solar radiations. Pterygium is found in the sunny, hot, dusty regions of the world, and more common in people who work in agricultural fields, labourers, etc. Working in dry and dusty place is the cause of pterygium. A number of hypotheses have been approved to its etiology.[2] Now, it is believed that Pterygium most likely due to growth disorder characterized by conjunctivalisation of the cornea could be due to localized ultraviolet stimulated damage to the limbal stem cells.[3] Destructive Pterygial fibroblasts is one of the reason responsible for corneal invasion.

Financial or Other, Competing Interest: None.

Submission 18-12-2015, Peer Review 19-12-2015,

Acceptance 28-12-2015, Published 31-12-2015.

Corresponding Author:

Dr. Amar Kanti Chakma

Associate Professor,

Department of Ophthalmology,

Tripura Medical College, Hapania,

Agartala-14.

E-mail:amarkanti@yahoo.com

DOI:10.14260/jemds/2015/2580
The excision of a pterygium with no added therapy (Bare sclera technique) was widely practised because it was believed to be safe and simple. However, it became apparent that the recurrence rate was unacceptably high ranging from $32 \%$ to $88 \%$. Several methods were implemented with the aim of improving the success rates, among them conjunctival autograft was one of the recent recommended techniques. This study concerns itself with a clinical study of pterygium excision with conjunctival autograft in diabetes and nondiabetes patient in order to determine the safety of the procedure in terms of complications and success rate of the procedure in terms of recurrence.

\section{MATERIALS AND METHODS}

It is a retrospective study conducted at Department of Ophthalmology in collaboration with Department of Medicine from November 2011 to October 2013. We randomly selected 100 eyes making Group A with type 2 diabetes and Group B without Diabetes comprising 50 eyes in each group. After surgery, patients will be followed up monthly for a period of 6 months to look for recurrence. All patients with diabetes were evaluated by medicine department and cases were taken for surgery after proper diabetic control. A written informed consent explaining the complications and possibility of recurrence was obtained from all patients. All patients underwent pterygium excision with conjuctival autografting.

\section{Inclusion Criteria}

All cases of operable pterygium were taken up for surgery and studied .Only patients with primary pterygium were included in the study. 


\section{Exclusion Criteria}

Recurrent Pterygium, any previous ocular surgery, previous ocular trauma, age below 30 yrs and or any existing ocular disease.

All patients included in the study underwent the following examination: Visual acuity testing, Refraction and best corrected vision, slit lamp biomicroscopic examination was done for all patients and following were noted: Location of the pterygium, Progressive or non-progressive, Extent of the pterygium encroachment into the cornea was estimated.

\section{Surgical Procedure}

Peribulbar anesthesia was given with $2 \%$ lignocaine and $0.5 \%$ bupivacaine. The surgical field was painted with Betadine and draped with sterile drapes. Universal eye speculum was used to separate the lids and expose the surgical field. The head of the pterygium was grasped with a fine-toothed forceps and the head was dissected off from the cornea with a crescent blade up to the limbus. The body of the pterygium was dissected and excised. The excised area included a $1 \mathrm{~mm}$ border beyond the edges of the excised head at the limbus. The globe was turned inferiorly and lignocaine $2 \%$ was injected subconjunctivally in the supero-temporal quadrant to form a bleb and separate conjunctiva from the Tenon's Capsule. Westcott's scissor was used to cut a conjunctival flap of the exact size of the receiving scleral bed measured using calipers.

The exact limbal orientation of the conjunctival graft was maintained and shifted to the receiving bed. The donor site was covered by pulling the superior forniceal conjunctiva and anchoring it to the limbal episcleral tissue with one 8-0 vicryl suture. The graft was sutured using 8-0 vicryl interrupted sutures with the bites incorporating the episclera at limbal side. Post-operatively, the patients were evaluated for visual acuity, condition of the cornea (Amount of opacity - nebular, macular, leucoma), condition of the graft (Retraction, chemosis, haemorrhage, congestion), Condition of the donor site. Post-operatively, the patients were started on topical antibiotic-steroid combination eye drops 8 times a day and tear substitutes 4 times a day.

The antibiotic drops were stopped after a period of 2 weeks and tapering doses of steroids, tear substitutes were continued for 1 month. Patients were then evaluated with respect to visual acuity, presence or absence of recurrence and complications at 1 week, 1 month, 2 months, 4 months and 6 months. Recurrences were considered as encroachment of the cornea by vascularization more than $1.5 \mathrm{~mm}$ along with presence of conjuctival drag. Vascularization without conjuctival drag was not considered as recurrence.

\section{RESULTS}

In group A with diabetes out of 50 patients, 16 (32\%) were male, $34(68 \%)$ were female and in group B without diabetes $30(60 \%)$ were male and $20(40 \%)$ were female.

\begin{tabular}{|c|c|c|}
\hline Age (Years) & Numbers & Percentage \\
\hline $30-39$ & 12 & $24 \%$ \\
\hline $40-49$ & 18 & $36 \%$ \\
\hline $50-59$ & 14 & $28 \%$ \\
\hline 60 and Above & 6 & $12 \%$ \\
\hline \multicolumn{2}{|c|}{ Table 1: Group A: Patient with Diabetes, } \\
Age wise distribution \\
\hline
\end{tabular}

In group A, 12 (24\%) patients came under 30-39 years category, 18 (36\%) and 14 (28\%) belongs to 40-49 and 50-59 years category respectively. In group B, out of 50 patients, 11 eyes $(22 \%)$ belonged to $30-39$ yrs. age group 17 eyes (34\%) belonged to 50-59 yrs. age group, 7 eyes (14\%) belonged to 60 years and above group.

\begin{tabular}{|c|c|c|}
\hline Age (Years) & Numbers & Percentage \\
\hline $30-39$ & 11 & $22 \%$ \\
\hline $40-49$ & 15 & $30 \%$ \\
\hline $50-59$ & 17 & $34 \%$ \\
\hline 60 and Above & 7 & $14 \%$ \\
\hline \multicolumn{2}{|c|}{ Table 2: Group B: Patient without Diabetes, } \\
Age wise distribution \\
\hline
\end{tabular}

\begin{tabular}{|c|c|c|}
\hline Types of Pterygium & Group A & Group B \\
\hline Progressive & 46 & 4 \\
\hline Non-progressive & 42 & 8 \\
\hline \multicolumn{2}{|c|}{ Table 3: Types of Pterygium } \\
\hline
\end{tabular}

\begin{tabular}{|c|c|c|c|c|}
\hline Complication & \multicolumn{2}{|c|}{ Total No. } & \multicolumn{2}{c|}{ Percentage } \\
\hline & $\begin{array}{c}\text { Group } \\
\text { A }\end{array}$ & $\begin{array}{c}\text { Group } \\
\text { B }\end{array}$ & $\begin{array}{c}\text { Group } \\
\text { A }\end{array}$ & $\begin{array}{c}\text { Group } \\
\text { B }\end{array}$ \\
\hline Graft Rejection & 4 & 7 & $8 \%$ & $! 4 \%$ \\
\hline $\begin{array}{c}\text { Subconjuctival } \\
\text { haemorrhage }\end{array}$ & 8 & 9 & $16 \%$ & $18 \%$ \\
\hline Loose sutures & 5 & 4 & $10 \%$ & $8 \%$ \\
\hline Corneal thinning & 0 & 2 & 00 & $4 \%$ \\
\hline Inclusion cyst & 0 & 0 & 00 & 00 \\
\hline $\begin{array}{c}\text { Sclerocorneal } \\
\text { dallen }\end{array}$ & 3 & 0 & $6 \%$ & 00 \\
\hline Granuloma & 1 & 2 & $2 \%$ & $4 \%$ \\
\hline \multicolumn{6}{|c|}{ Table 4: Post-operative Complication } \\
\hline
\end{tabular}

Among 50 operated cases in group A, graft retraction was noted in 4 cases (8\%), subconjunctival hemorrhages was noted in 8 cases $(16 \%)$, loose sutures was noted in 5 cases $(10 \%)$ and there is no corneal thinning. In group B, graft retraction was noted in 7 cases $(14 \%)$, subconjunctival hemorrhages was noted in 9 cases (18\%), loose sutures was noted in 4 cases (8\%) and there is corneal thinning in 2 cases.

\begin{tabular}{|c|c|c|}
\hline \multirow{2}{*}{ Characteristics } & \multicolumn{2}{|c|}{ Number of Patients } \\
\hline & Group A & Group B \\
\hline No. of Recurrences & 5 & 3 \\
\hline Mean Time (In month) & 4 & 5.3 \\
\hline Progressive & 4 & 3 \\
\hline Regressive & 1 & 0 \\
\hline \multicolumn{3}{|c|}{ Table 5: Recurrences of Pterygium } \\
\hline
\end{tabular}

Out of 50 operated cases in group A for pterygium excision with conjuctival auto graft, 5 cases had recurrence whereas 3 cases had recurrence in Group B. Almost all the recurrences occurred in progressive type of pterygium in both the groups.

\section{DISCUSSION}

Total 100 patients were included in our study. They underwent pterygium excision with Conjunctival autograft technique. In our study, number of males were $16(32 \%)$ in group A and 30 (60\%) in Group B and females were 34 (68\%) in group A and $20(40 \%)$ in group B. It was seen that, females in our study in addition to doing housework also work in fields and get exposed to UV rays dust and wind. In a study done by Riordan-Eva et al (1993).(4) 66 cases (61\%) were males and 42 cases $(38.89 \%)$ were females. In our study, the patients were in the age group between 30-60 years and above, highest numbers of patients were in the age group 40-49 years (36\%) in group A and in group B in the age group of $50-59$ years (34\%). Lowest numbers of cases were in the age group $\geq 60(12$ $\%$ ) in group A and $14 \%$ in group B. Mean age was $46.56 \pm 10.78$ years .In the study done by Riordan-Eva et al (1995)..[4] age of patients ranged from 25-77 years. Mean age in that study was 47 years. In another study done by Philip Chen, et al. (1995).[5] 
ages of patients ranged from 23-79 years. Mean age in that study was 45.6 years. These two studies correlate with the present study.

In our study, 46 cases (92\%) and 42 cases (84\%) were progressive in group A and B respectively and 4 cases (8\%) and 8 cases $(16 \%)$ were non-progressive pterygium in group A and B respectively. In a study by Donald Tan, et al. (1997), 124 cases $(78.34 \%)$ were progressive pterygium and 34 cases $(21.66 \%)$ were non-progressive pterygia.[6] In the present study, we did not encounter any intra-operative complication during surgery. All the surgeries were done under local anesthesia and minor post-operative complications as 5 and 4 cases of loose sutures were seen in group A and B respectively, which did not require any active intervention, 4 and 7 cases of graft retraction were seen in group $A$ and $B$ respectively due to use of a small graft of $5 \times 5 \mathrm{~mm}$ size, 7 and 9 cases of subconjunctival hemorrhage were seen in group A and B respectively, which did not require any active intervention.

In our study we got granuloma and sclera-corneal dellen in both the groups, but did not encounter epithelial inclusion cyst. In a study by Chen P, et al. (1995), 1 case (5.88\%) of granuloma and 1 case of epithelial inclusion cyst (5.88\%) seen in Bare Sclera group and 1 case $(4.35 \%)$ of loose suture and 1 case $(4.35 \%)$ of dellen seen in conjunctival autograft group..$^{[5]}$ In a study by Chee SP, et al. (2000), 4 cases (2.88\%) developed granuloma at donor conjunctival site and 3 patients had $(2.16 \%)$ conjunctival cyst on the graft, 1 case $(0.72 \%)$ developed scleral thinning in Conjunctival Autograft group.[7] In a study by Jap A, et al. (1999), pigmentary changes were noted in 6 grafts $(12 \%)$ following conjunctival rotation autograft. In a study by Gris 0, et al. (2000), one case of graft retraction was seen.[8-9]

In our study pterygium recurred in 5 cases $(10 \%)$ and 3 cases (6\%) in group A and B respectively out of 100 cases. In the present study, the average age of recurrence was 43.3 years. The average time of recurrence was almost 5.3 months after surgery. Recurrence was common in progressive pterygium. It is seen that younger age appears to be a risk factor for recurrence. Hence patient's age should be taken into consideration before taking up for surgery. In a study by Lewallen, et al. (1998), patients younger than 37 years showed a higher risk of pterygium recurrence. In another study by Sharma A, et al. (2000); all cases of recurrence occurred in patients below 40 years of age.[10-11] Conjunctival autograft technique has a recurrence rate of $5 \%$ to $39 \%$.

The wide range of recurrence rates reported has been attributed to various study difference including methodology (Prospective/retrospective), patient characteristics (Race, age); nature of pterygium (Advance, recurrent, progressive), geographic area of domicile; number of patients studied, definition of recurrence, duration of follow-up, loss to followup, surgical technique and surgeons experience. On reviewing published literature we feel surgical technique could probably be the single most factor influencing recurrence. The meticulousness with which the limbal tissue is included in the autograft in our opinion determines the success of the procedure. Authors like Guler, Prabhaswat, Mutlu and Allan Bruce have specifically described the inclusion of limbal tissue in the graft and have reported low recurrence rate.[12-15] Conjunctival autograft technique is a safe and effective technique with problems including greater surgical skill, use of operating microscope, with extended operating time, surgical disturbance of superior bulbar conjunctiva.

There is no significant difference between complications, types of complications and recurrences between diabetes and non-diabetic patient.

\section{CONCLUSION}

Autogenous conjunctival grafting is a safe, uncomplicated, quick procedure with low recurrence rate. There is no significant difference in recurrences in diabetic and nondiabetic patient except delayed in healing in diabetic patient.

\section{REFERENCES}

1. Jack J Kanski, Brad Bowling. Clinical ophthalmology a systematic approach, 7th Edition, Elsevier; 2011.

2. Hiwt L. Distribution, risk factors and epidemiology. In Taylor HR (ed) Pterygium. Vol 2. The Hague, Netherlands: Kugler Publications; 2000. pp. 15-28.

3. Dushku N, Reid TW. Immunohistochemical evidence that human pterygia originate from an invasion of vimentin expressing altered limbal epithelial basal cells. Curr. Eye Res 1994;13:473-81.

4. Riordan-Eva P, Kielhorn I, Ficker LA. Conjunctival autografting in the surgical management of pterygium Eye 1993;7:634-638.

5. Chen Philip, Reginald G Ariyasu, Venu Kaza. A randomized trial comparing mitomycin $\mathrm{C}$ and conjunctival autograft after excision of primary pterygium. American Journal of Ophthalmology 1995;120:151-160.

6. Tan DH, Soon-Phaik Chee, Keith BG Dear. Effect of pterygium morphology on pterygium recurrence in a controlled trial comparing conjunctival autografting with bare scleral excision. Arch Ophthalmology 1997;115:1235-1240.

7. Ti SE, Chee SP. Analysis of variation in success rates in conjunctival autografting for primary and recurrent pterygium. British Journal of Ophthalmology 2000;84:385-389.

8. Jap A, Chan C, Lim L. Conjunctival rotation autograft for pterygium. An alternative to conjunctival autografting. Ophthalmology 1999;106(1):67-71.

9. Gris 0 , Guell JL. Limbal-conjunctival autograph transplantation for the treatment of recurrent pterygium. Ophthalmology 2000;107(2):270-3.

10. Lewallen S. A randomized trial of conjunctival autografting for pterygium in the tropics. Ophthalmology 1989;96(11):1612-4.

11. Sharma A, Gupta A. Low-dose intraoperative mitomycin$\mathrm{C}$ versus conjunctival autograft in primary pterygium surgery: Long-term follow-up Ophthalmic Surg. Lasers 2000 July-August; 31(4):301-7.

12. Guler M, Sobaci G. Limbal conjunctival autograft transplantation in cases with recurrent pterygium. Acta Ophthalmol (Copcnh) 1994 Dec; 72(6):721-6.

13. Prabhasawat Pinnita; Keith Barton. Comparison of conjunctival autografts, amniotic membrane grafts and primary closure for pterygium excision. Ophthalmology 1997;104:974-985.

14. Mutlu FM, Sobaci G. A comparative study of recurrent pterygium surgery: limbal conjunctival autograft transplantation versus Mitomycin C with conjunctival flap. Ophthalmology 1999 April;106(4):817-21.

15. Allan Bruce DS, Perry Short. Pterygium excision with conjunctival autografting: an effective and safe technique. British Journal of Ophthalmology 1993;77:698-701. 